\title{
Comparative Survey of Lignification in Aerial Organs during Development of Sugarcane (Saccharum officinarum L.)
}

\author{
Maryam Kolahi ${ }^{1, *}$, Mohammad Reza Tabandeh ${ }^{2}$, Majd A $^{3}$, Parisa Jonoubi ${ }^{3}$, Mahmoud Hashemitabar \\ ${ }^{1}$ Department of Biology, Faculty of Science, Shahid Chamran University of Ahvaz, Iran \\ ${ }^{2}$ Department of Biochemistry and Molecular Biology, Faculty of Veterinary Medicine, Shahid Chamran University of Ahvaz, Iran \\ ${ }^{3}$ Department of Plant Sciences, Faculty of Biological Sciences, Kharazmi University, Postal Code 15719-14911, Tehran, Iran \\ ${ }^{4}$ Cellular and Molecular Research Center, Faculty of Medicine, Ahvaz Jundishapur University of Medical Sciences, Iran \\ *Corresponding Author: m.kolahi@scu.ac.ir,m.tabandeh@scu.ac.ir, e.shomeili@gmail.com, hashemi_tabar@hotmail.com
}

Copyright $\mathrm{O} 2018$ by authors, all rights reserved. Authors agree that this article remains permanently open access under the terms of the Creative Commons Attribution License 4.0 International License

\begin{abstract}
Cell-wall lignification is among the new features that appeared as early plants began to adapt to land, possibly aiding in the development of more complex bodies. Saccharum officinarum L., a typical C4 plant with unique structure and anatomy, is one of the most important energy crops in the world with a very high yield of biomass. We analyzed lignification in the anatomy of leaf, sheath and stem, in sugarcane seedlings at four distinct stages of growth: germination stage, tillering stage, ground growth stage and maturation stage. Kranz anatomy with well-developed bundle sheath associated with Kranz mesophyll was observed but Kranz system was absent in large vascular bundles. Lignification of tissues and cells in sheath during early developmental stages is expected confirmed because during this stage, when stem tissue is absent in sugarcane, may be critical for the expansion of lignification and development of the stem and increasing the mechanical rigidity of the young plant. The lignified tissues and the intensity of lignification increased during later stages of development, especially in the stem. The most lignified tissues of the stem can be observed during the maturation stage and a little before it, which provides the stem with mechanical strength. These differentiation features may be linked to stem development, while the relevant changes in metabolites may be related to sucrose accumulation.
\end{abstract}

Keywords Developmental Stage, Lignification, Sugarcane, Tissue

\section{Introduction}

Sugarcane belongs to the genus Saccharum L., of the tribe Andropogoneae in the grass family (Poaceae).
Sugarcane is a tall-growing monocotyledonous crop plant, cultivated in the tropical and subtropical regions of the world, primarily for its ability to store high concentrations of sucrose, or sugar, in the internodes of the stem. Modern sugarcane varieties that are cultivated for sugar production are complex interspecific hybrids (Saccharum spp.) that have arisen through intensive selective breeding of species within the Saccharum genus, primarily involving crosses between the species Saccharum officinarum L. and $S$. spontaneum L. [1].

Sugarcane farming and sugar industry also hold special importance in the agricultural development and economy of Iran. Sugarcane is one of the economically important crops of Iran, providing employment to about 50,000 people and contributing to the growth of the vital rural economy [2].

The process of refining sugar is said to have been worked out at Jundi Shapur city in Khuzestan province (SW Iran) since 600 years ago [3]. Khuzestan is responsible for more than $99 \%$ of sugarcane produced in Iran and can play an important role in satisfying future ethanol demand as an attractive renewable energy resource [4].

An appreciation of anatomy is fundamental in order to understand many aspects of plant biology, including ecological and molecular ends of the spectrum. It is therefore a cause for concern that plant anatomy is increasingly marginalized in biology studies [5].In recent years, it has been widely accepted that plants undergo physic development [6,7]. Some plants display distinct and abrupt changes in organ morphology or anatomy, whereas other plants show a more subtle and gradual transition between developmental phases [8,9]. Regardless of how phase change is displayed in a plant, its regulation is a complex process involving the interplay of environmental, hormonal, and genetic factors [10-15]. Lignification of 
plant tissue as developmental hallmark varies among parts of the same plant and also changes as plants mature. Because of developmental regulation of lignification, it is expected that genes responsible for lignin biosynthesis will also be developmentally regulated. Lignification and lignin accumulation in cell wall results in a three-dimensional network that offers rigidity to the cell wall and, therefore, limits cell growth [16]. Lignification contributes to the protective mechanism against compression and tensional stress in cells [17]. However, lignin is the major component of the cell wall that is recognized as negative index of sugar and paper industry, there is any relationship between lignification and sugar content in sugarcane, in fact lignification and cellulose constitute are be occurred in plant cell wall, but save the sugar in the some inner compartments of stem cells such as cytoplasm, vacuoles, etc. occurs [18].

Sugarcane, a typical C4 plant with unique structure and anatomy, is one of the most important energy crops in the world with a very high yield of biomass [19]. Using sugarcane in different developmental stages seedlings, we addressed the analyzing leaf, sheath and stem anatomy. This study will give a new perspective for understanding both plant development and the anatomy changes of in different locations within the plant specially lignified parts. Four distinct periods or phases of growth are often recognized: germination stage, tillering stage, ground growth stage and maturation stage [20,21]. The lignification process in various parts of the sugarcane plant is one of developmental and natural steps in sugarcane development. Certainly there are differences between different varieties of sugar cane in terms of the rate and speed of lignification. It seems that can be used of this feature to select suitable varieties according to our target and its application. For example, in parts of the sugar cane agro-industry that aims to produce paper must be used to cultivate the varieties with less amount of lignification on the cells walls. Because whatever the amount of lignification of cell walls being less the so extraction and purification of raw material of paper is more convenient.

\section{Materials and Methods}

Samples of commercial sugarcane (cultivar CP69-1062) were taken during different developmental stages. The germination stage, 15 to 30 days after planting, the tillering stage 50 to 120 days, the grand growth phase 121 to 210 days and the maturity stage 210 to 365 days. Plant materials were grown on a farm at the Sugarcane Research Center, Agro-industrial Co., a region situated in the province of Khozestan (Ahvaz, Iran). The plant samples were taken in three replicates. Samples were taken and fixed in ethyl alcohol-formaldehyde-acetic acid (F.A.A) from each plant: lamina, sheath from the last fully expanded leaf, and stem from $7^{\text {th }}$ and $8^{\text {th }}$ internodes. Free hand sections were cut and stained in carmine and methyl blue. Thin cut sections were observed under a research microscope (Olympus BX-51) fitted with digital camera (Olympus DP80) and attached with computer. Plant tissues cross-section anatomy was studied through taking micro-photographs.

\section{Results}

\section{Anatomy of Sugarcane Leaf during Different Development Stages}

At transverse section, the leaves exhibited smaller ribs arranged close to midrib. (Figure A-1). The bulliform cells are located in the upper epidermis except midrib region. The ribs are surrounded by fiber cells. Vascular bundles consisted of xylem with large vessels and phloem including companion cells, sieve elements and parenchyma cells. Three orders of vascular bundle length were observed in the mesophyll, large, intermediate and small vascular bundles. Kranz anatomy is just recognized around the intermediate and small vascular bundles (figure 1-A, B; 2B, D). chronchyma mesophyles radically around bundle sheaths. The layer of Kranz mesophyll surrounding vascular bundles is dispersed from one another by a layer of non- Kranz cell failing chloroplast (figure 2-D). The bulliform cells are large, spherical, as the eight categories including and without pigment (figure 1- D; 2- I). The large vascular bundles were rhomboid or oval in contour and small vascular bundles were round (Figure 1-A-D). The mesophyll cells are spherical, lack clarity and with a lot intercellular air spaces among them, connected with sub-stomatal chambers (figure 2-G).

Large vascular bundles of leaves have two large metaxylem sides of protoxylème or hole of metaxylem. Protophloem is visible but usually disappears in mature bundles, and only the metaphloem is functionable (figure $1-\mathrm{E}, \mathrm{F}, \mathrm{G})$.

Some metaxylem cell walls are well-lignified. Phloem bundles contain both thin-walled and thick-walled sieve elements. The large vascular bundles with no Kranz anatomy are surrounded by the vascular sheath and are kept by hypodermal sclerenchyma. The intermediate and small bundle vascular sheath cells are always bordered by Kranz mesophyll (figure 1-E, F, G). Central midrib large bundle is flanked by 3-10 small bundles on either side of midrib which have Kranz system of anatomy (figure 2-A, B). These bundles have an active role in plant photosynthesis. Bundle sheath cells are numerous, thicker and larger in size in large bundles compared to intermediate and small bundles (Figures $1 \& 2$ ). The cells around of vascular bundles have formed sclerenchymatous bundle cover. Unlike large vascular bundles, intermediate vascular bundles have small metaxylem vessels they may have metaphloem (figure 1-D, E, F). Midrib anatomy differs 
from leaf blade. The ground tissue of midrib is composed of large colorless parenchymatic cells which account for most of the thickness of the leaf blade midrib (Figs. 1A-D). The region has a very large central longitudinal vascular bundle much deep inside the ground tissue under the abaxial surface. Vascular bundles in the midrib region are associated with longitudinal patches or strands of hypodermal sclerenchyma formed beneath the abaxial epidermis, which can prevent the mechanical destruction of the leave. In addition, in the midrib region, a continuous sub-epidermal layer of sclerenchyma exists. Small vascular bundles are not surrounded by sclerenchyma bundle sheath, and intermediate vascular bundles are enclosed by sclerenchyma bundle sheath with thinner cell walls and the intensity of lignification is less than in large vascular bundles (figure 1-G, I).

Anatomical structure of leaves at germination stage in comparison with the next stages, indicated that more tissue structures are formed and enlargement of the dimensions of the leaves are often observed. Significant differences were not seen in the anatomical structure of leaves between the germination stage and other stages of development (figure $1 \& 2)$. The central vascular bundles of leaves in the germination stage were about 6 , while at the tillering stage increased to 10 bundles and at later stages of development vascular sheath thickness and lignification are increased (figure 1-A, 2-I). At the tillering stage, in comparison with the germination stage, the number of bundles in the central and peripheral region were more as well as the hypodermis sclerenchyma cells layer and their wall thickness were increased. The number of layers of the sclerenchyma cells under the upper epidermis was a two-cell layer, while at the tillering stage increased to more than 3 layers, and at later stages of development the walls were thicker and more lignified (figure 1-D-I). Phloem tissues at the tillering stage were more developed relatively to the germination stage and the intensity of color and thickness of the cells was increased (figure 1-C, E, F, G). The number of vascular sheath cell layers at the tillering stage was 2-3 layers of cells and the walls were relatively thick (figure 1-C, E, F, $\mathrm{G}$ ). At the germination stage the intensity of cell wall lignification in vascular bundle sheath was low, the walls were not very thick and in the place of phloem several layers of cells with thick walls were seen (figure 1-A, B, C). At the germination stage 6 layers of mesophyll cell were present in the midrib, while at the tillering stage 8 layers of cells were observed, and at later stages the size of the cells was augmented (figure $1 \& 2$ ). In the grand growth stages, bulliform cells were coarser (figure 1-B, C, and E). At the stage of maturation, phloem cell wall was thicker, the thickness of the hypodermis sclerenchyma cells increases up to 5 layers and cell walls were thicker. Starch density in field's cells and diameter of vessel was also increased. The difference in the size of the main vein between growth stage and the previous stages was obvious (figure 1- E, G, H, I).

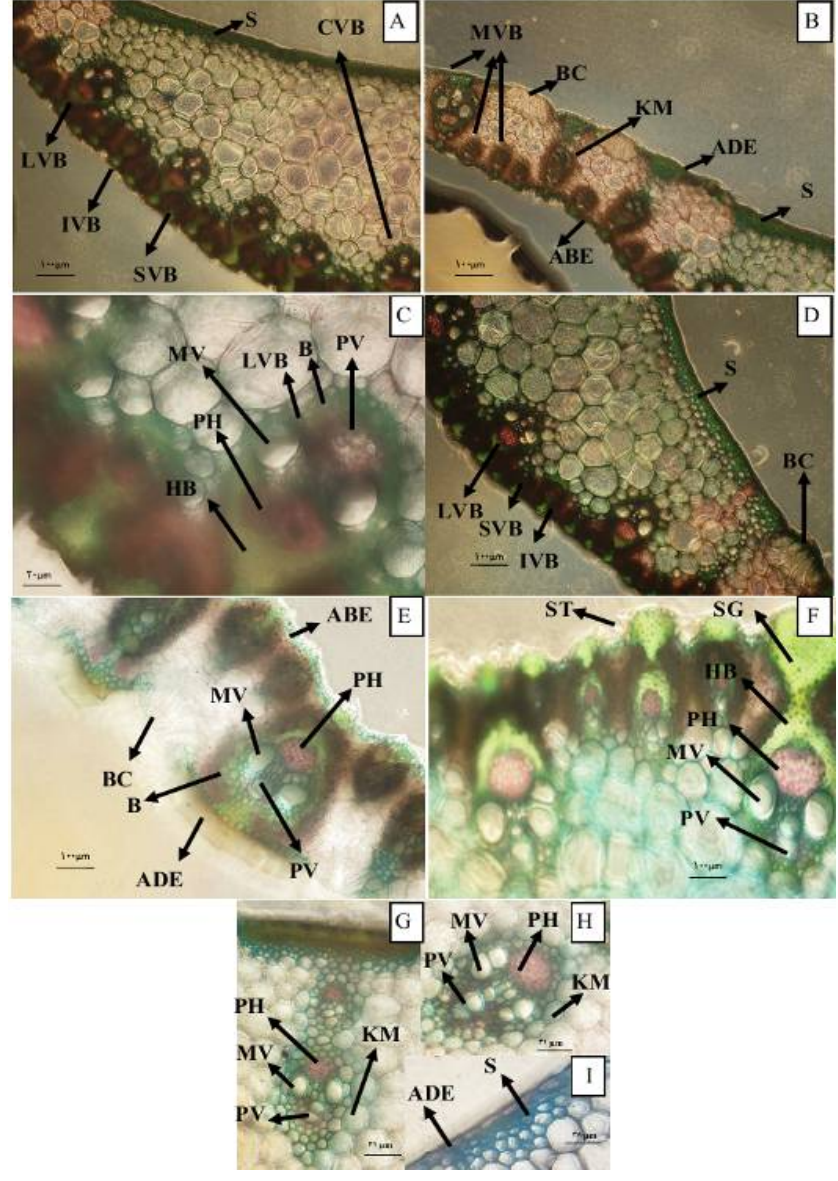

Figure 1. Transverse section of sugarcane leaf, A, B, C at germination stage and $\mathrm{D}, \mathrm{E}, \mathrm{F}, \mathrm{G}, \mathrm{H}$ at tillering stage. $\mathrm{S}=$ hypodermal sclerenchyma; $\mathrm{BC}=$ bulliform cell; $\mathrm{LVB}=$ large Vascular bundle; IVB = intermediate vascular bundle; $\mathrm{SVB}=$ small vascular bundle; $\mathrm{ABE}=$ Abaxial epiderm; $\mathrm{ADE}=$ Adaxial epiderm; $\mathrm{Sg}=$ sclerenchymatous girder; $\mathrm{b}=$ bundle sheath; $\mathrm{km}=$ Kranz mesophyll; $\mathrm{pv}=$ protoxylem vessel; $\mathrm{mv}=$ metaxylem vessel; $\mathrm{ph}=$ phloem $; \mathrm{m}=$ mestome sheath

\section{Anatomic Structure of Sugarcane's Sheath during Different Development Stages}

The vascular bundles of sheath are parallel to each other. Sheath vascular bundles have different sizes. In the sides of the sheath, vascular bundles are alternately large and small, while in the middle of the sheath mid-sized vascular bundles are found. The smallest bundles were formed close to the epidermis, lacking protoxylem because they were formed later during development. Sclerenchymatous bundle cover was close to the xylem pole, developed in the phloem region and usually in the confluence with the sclerenchyma of hypodermis. The intermediate and large vascular bundles have protoxylem, but often lack the sclerenchyma hypodermis or are isolated from it by several rows of parenchyma cells. The cap of phloem bundle was in contact with the sclerenchyma hypodermis, except for the bundles which were located near the center (figure 2-A, B). 

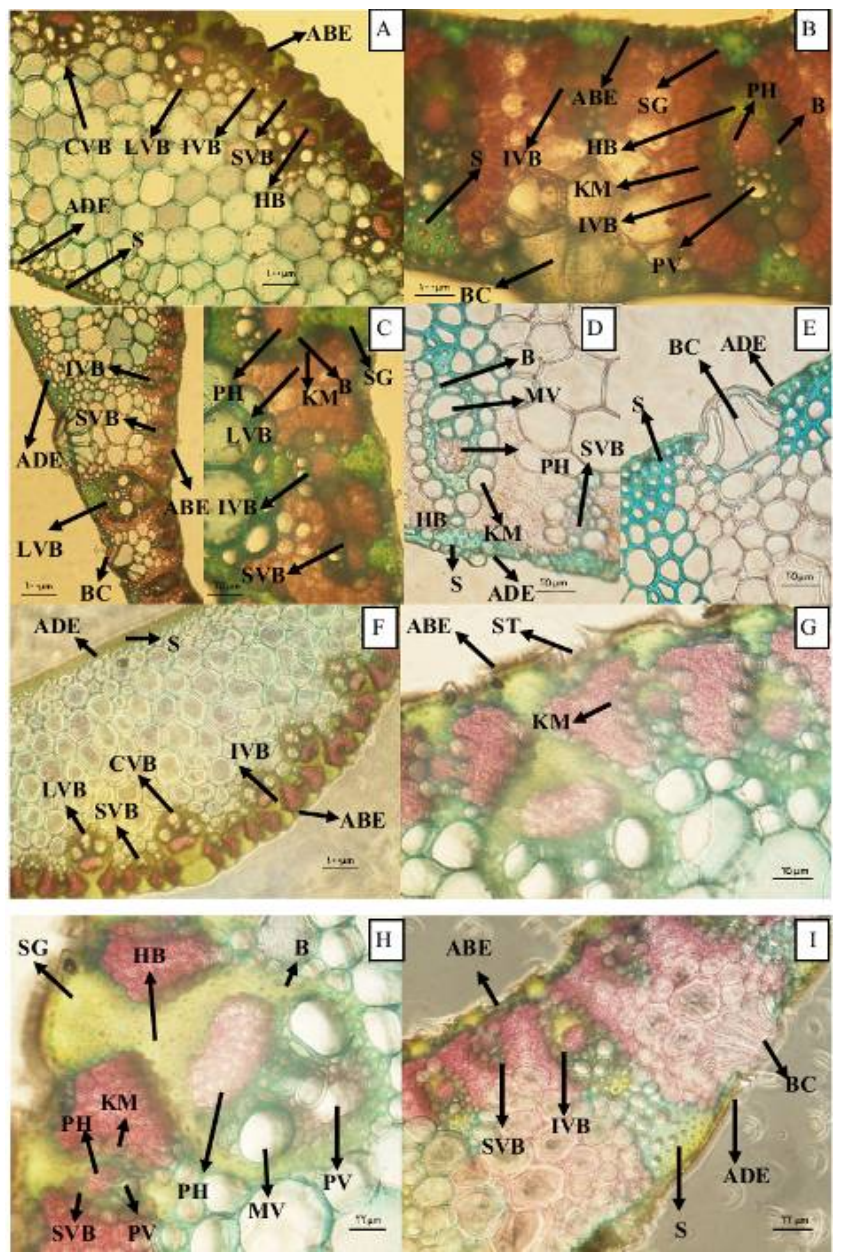

Figure 2. Transverse section of leaf blade of sugarcane, A, B, C, D, E in ground growth stage and F, G, H, I in maturation stage during development of sugarcane, $\mathrm{S}=$ hypodermal sclerenchyma; $\mathrm{BC}=$ bulliform cell; $\mathrm{LVB}=$ large Vascular bundle; IVB = intermediate vascular bundle; $\mathrm{SVB}=$ small vascular bundle; $\mathrm{ABE}=$ Abaxial epiderm; $\mathrm{ADE}=$ Adaxial epiderm; $\mathrm{Sg}=$ sclerenchymatous girder; $\mathrm{b}=$ bundle sheath; $\mathrm{km}=$ Kranz mesophyll; $\mathrm{pv}=$ protoxylem vessel; $\mathrm{mv}=$ metaxylem vessel; $\mathrm{ph}=$ phloem; $\mathrm{m}=$ mestome sheath

In the xylem pole, collenchyma cells about 5 cells were radically placed and by small groups were connected to the sclerenchyma hypodermis of lower epidermis (figure 3- B). The area between radial collenchyma cells with large empty cells had been filled. The field of old sheath appears sponge white tissue but the cells often break down. The internal epidermis consisted of thin-walled elongated cells. Anatomical structure of sheath at germination stage, in comparison with next stages, did not exhibit significant differences and increase the dimensions of sheath was often seen (figure 3-B, C).

At the tillering stage, on the inner epidermis sclerenchyma cells mass in front of the xylem pole as the hypodermis is shaping up. At this stage, parenchyma cells of ground tissues are larger, the number of vascular sheath cells layers and the amount of lignified cell walls increased. The number of sclerenchymatous cells under internal epidermis to the side of vascular bundles increased (figure
2-C, D). The difference between the grand growth and maturation stage in this category had never seen. The cell wall thickness of outer epidermis was thicker from this stage onwards. From germination stage to tillering stage, the distance of vascular bundles was less and gradually became more compact. At the grand growth stage, the lignified sclerenchymatous cells under the interior epidermis were completely developed to the protoxylem pole and connected to vascular bundles (figure 2-E, F).
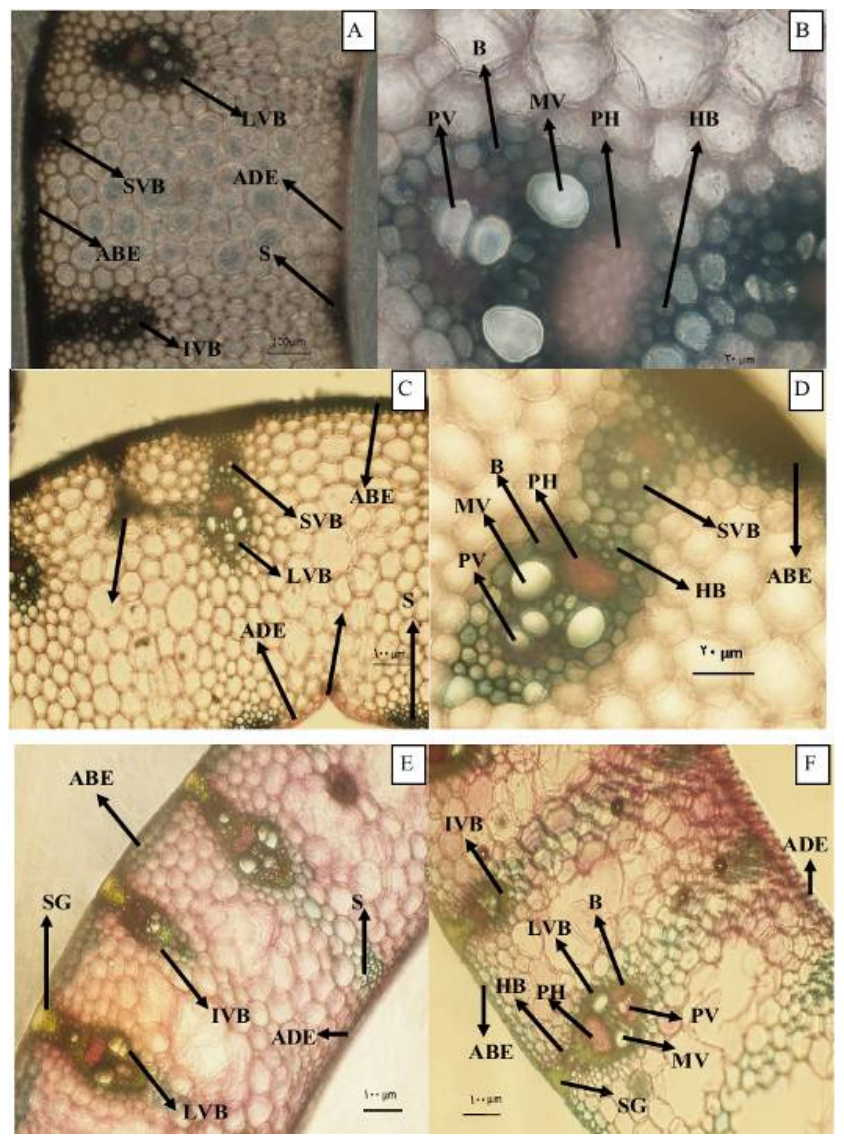

Figure 3. Transverse section of sheath of sugarcane. A, B in germination stage, C, D in tillering stage, and D, E, F, G, H in tillering stage, $\mathrm{E}$ in ground growth stage and $\mathrm{F}$ in maturation stage during development of sugarcane, stage during development of sugarcane, $\mathrm{S}=$ hypodermal sclerenchyma; LVB = large Vascular bundle; IVB = intermediate vascular bundle $\mathrm{SVB}=$ small vascular bundle; $\mathrm{ABE}=$ Abaxial epiderm; $\mathrm{ADE}=$ Adaxial epiderm; $\mathrm{Sg}=$ sclerenchymatous girder; $\mathrm{b}=$ bundle sheath $; \mathrm{km}=$ Kranz mesophyll; $\mathrm{pv}=$ protoxylem vessel; $\mathrm{mv}=$ metaxylem vessel; $\mathrm{ph}=$ phloem; $\mathrm{m}=$ mestome sheath.

\section{Anatomical Structure of Sugarcane Stem during Different Developmental Stages}

At the germination stage, the stem was not yet formed, so the anatomical structure of the stem were studied at the next stages. At transverse section of stem the following structure was observed. Epidermis is the outermost layer of the stem, represented by a single layer of compactly arranged, barrel-shaped epidermal cells with no intercellular spaces. The cells exhibited slightly thick wall. 
Numerous multicellular trichomes emerge from the epidermis. Hypodermis is a layer immediately below the epidermis, consisting of a few layers of sclerenchyma cells with angular thickenings. The cells are compactly arranged without any intercellular spaces. Hypodermis provides mechanical support and additional protection. Ground tissue is a major component of the stem. It appears undifferentiated, consisting of several layers of loosely arranged parenchyma cells with prominent intercellular spaces, mainly functioning as storage of food (figure 4-A, E).

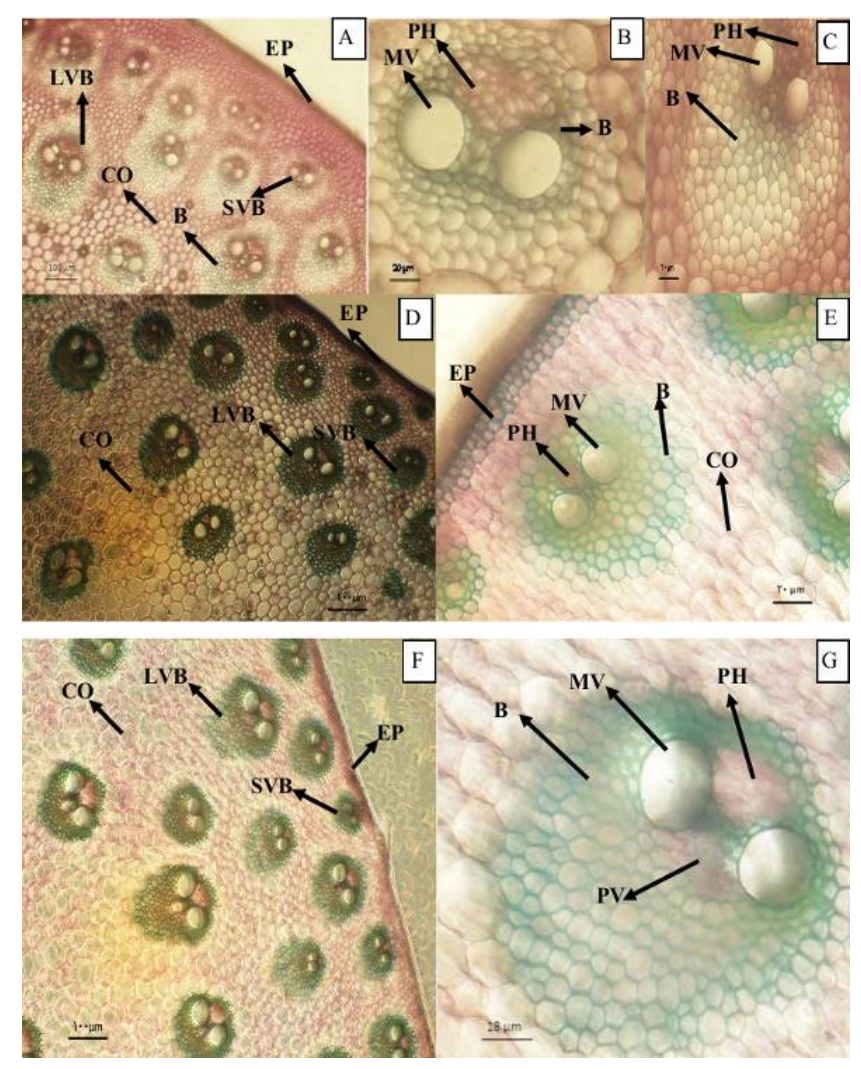

Figure 4. Transverse section of stem of sugarcane. A, B, C in tillering stage, E, D in ground growth stage, and F, G in maturation stage during development of sugarcane, stage during development of sugarcane, LVB $=$ large Vascular bundle; $\mathrm{SVB}=$ small vascular bundle; $\mathrm{IVB}=$ intermediate vascular bundle; $\mathrm{EP}=$ Epidermis; $\mathrm{B}=$ Bundle sheath; $\mathrm{CO}=$ Cortex $; \mathrm{pv}=$ protoxylem vessel; $\mathrm{mv}=$ metaxylem vessel $; \mathrm{ph}=$ phloem .

Vascular bundles are irregularly scattered and concentric in the ground tissue. Towards the periphery, the bundles are smaller in size while, towards the centre, they are larger in size. The smaller bundles are younger, while the larger ones are older; the arrangement is described as centrifugal. Ground tissue is composed of small, thick-walled sclerenchyma under the epidermis. These cell layers are followed by larger thin-walled parenchyma cells.. A cortex or pith is absent (figure 4-A, E). Thick-walled sclerenchyma fibers surround the vascular bundles, offering mechanical protection to them. (figure 4-A, B, C). The vascular bundles are conjoint, collateral and closed. In the xylem, there are two metaxylem and two protoxylem vessels arranged in a ' $\mathrm{Y}$ ' configuration. The lower protoxylem vessel is non-functional and remains as a water-filled cavity called lysigenous cavity or protoxylem cavity. In the phloem, only sieve tubes, companion cells and phloem fibres are present. Phloem parenchyma is absent (Figure 4-E, G). In the germination stage stem was not created and in comparison anatomical structure of stem in tillering stage to the next stages, more increase in stem diameter, increased densities and numbers of vascular bundles were be seen. More tissue structures in the same tillering stage have formed at the tillering stage, the vascular bundles were smaller and less numerous. Vascular sheath was present only near the protoxylem and protophloem. In the grand growth stage, the density and size of vascular bundles was increased And the sclerenchyma sheath around the vascular bundles was well-developed, so that the whole vascular bundle was surrounded. The thickness of vascular sheath, particularly near the protoxylem, and the degree of wall lignification were increased. In addition, the diameter of metaxylem elements was larger. At the stage of maturation, the sclerenchyma sheath of vascular bundles was developed (figure 4-A- G).

\section{Discussion}

From zygote to mature form, a plant develops through a series of changes, involving both growth and differentiation. For any organism, the term "growth" refers to quantitative and irreversible changes that take place during the life cycle. "Differentiation" applies to qualitative differences between cells, tissues, and organs that occur during the process of development [22].

Cell wall lignification is among the new features that appeared as early plants began to adapt to land, possibly aiding in the development of more complex bodies [23]. Modulation and variation in lignin content and composition has been studied in many plant species. These cases supply the basis for strategies of modification of lignin content and composition through genetic engineering [24]. This directed modification of lignin is likely to proceed through a series of steps, continuing to provide new information and novel phenotypes, related to lignin biosynthesis. An important barrier to such applications is still the inadequate gene-transfer systems for many of the most commercially important species, like sugarcane. The industrial uses of sugarcane products will provide economic incentives, even for small improvements in quality through modification in lignin [25].

The deposition of lignin must be regulated in conjunction with plant development. The spatial and temporal control of lignification is critical in plant support, water transport and disease resistance. Plants that are compromised in their ability to synthesize normal quantities of lignin lose their capacity to support the plant 
body [26-28] and, in some instances, to defend themselves against pathogens $[29,30]$. Lignin-deficient plants may be more sensitive to humidity fluctuations [31]. Proper lignin deposition is also important in controlling seed dispersal in some plant species [32].

The results of the present work demonstrate the vast changes in the degree of lignification in different tissues and organs during developmental stages. Histological study of the leaf indicated increase in lignification and thickness of vascular bundles, in the number of bundles in the central and peripheral region and in the number of layers of sclerenchyma cells. Comment the fact that sugarcane leaves in the end stages of growth to more than one meter so lignified structures is necessary for building strength of leaves. These results support that the highest accumulation of PePAL proteins, as enzyme that catalyzes the first reaction in phenylpropanoid pathway leading to the production of lignin, in bamboo was observed in leaf by Western blotting. Studies with immunohistochemistry showed that PePAL were localized primarily in vascular bundles and part of sclerenchyma cells of leaf and sheath. These results and biochemical properties can be providing the basis for molecular engineering to improve the quality of sugarcane products $[33,34]$.

Central large vascular bundles of midrib lack Kranz traits and have sclerenchyma bundle sheaths, implicated mainly in the maintenance and protection and less in photosynthesis. Similar results were also reported by Joarder et al [35].Lignification of tissues and cells in sheath during early developmental stages is important, because during this stage, due to stem absence, it may be critical for the expansion and development of the stem and may increase the mechanical rigidity of young plants [36]. In monocotyledonous plants, aerial pseudo-stems are created through the long, stiff sheath and leaf bases that are rolled around one other [37]. Also, the degree of lignification was coordinated with the activity of intercalary meristem cells of the young sheath, in order to ensure the relative diagonal growth of stems as common properties of monocotyledons $[38,39]$.

The increase of lignified tissues in the stem during the developmental stages of sugarcane is very noticeable when compared to other tissues of the plant. This change is an indication of the transformation of soft tissue in the stem, particularly during vascular bundle lignification. The concentric and peripheral vascular bundles are distributed within the stem, and the peripheral vascular bundles are normally greater in number and larger in size compared to the concentric ones [40]. The most lignified tissues of the stem can be observed during the maturation stage and a little before it, which offers resistance and strength in the stem. These differentiation features may be linked to stem development and those changes in metabolites may be related to sucrose accumulation [41,42]. At this stage, while the plant is increasingly growing in length, it strengthens and health becomes more critical, especially in the stem.

These results are in agreement with the findings of previous reports. This hypothesis was supported by the molecular data that genes involved in the lignin synthetic pathway were highly expressed in lignifying tissues, such as those of the stem. Four transcripts of the Arabidopsis $P A L$ genes have also been detected in the stem [43]. In the oldest internodes of wheat, during development, lignin content was highest. Therefore lignin deposition is regulated developmentally and increased gradually with stem maturity [44]. Investigation with transgenic plants and mutants indicates that the specific down-regulation of the expression of each gene involved in the lignin synthetic pathway induces changes not only in lignin content and composition but also in secondary cell wall formation in plant growth and development $[26,45,46]$.

In conclusion, this work characterized, for the first time, the anatomic structure of the aerial organs during development of sugarcane and analyzed the lignified tissues in different developmental stages. This study implies that lignified tissues and intensity of lignification increased during higher stages of development, especially in the stem. Kranz anatomy with well-developed bundle sheath associated with kranz mesophyll in the leaf was observed but Kranz system was absent from large vascular bundles. These bundles have an essential role in the maintenance and endurance in the leaf and their role in photosynthesis are less important. Finally, lignification is responsible for increasing the mechanical strength and sustainability of $S$. officinarum $\mathrm{L}$. The also indicated that the most lignified tissues were found in stem maturity, whereas internode maturity is associated with increased deposition of sugar.

\section{Acknowledgements}

This work was funded by a grant from the Shahid Chamran University of Ahvaz Research Council (Grant $\mathrm{N}^{\circ}$ : p.2.2186, 1392.10 .8). The authors declare that there is no conflict of interest.

\section{REFERENCES}

[1] Cox M, H.M., Smith G. (2000) Cane breeding and improvement .In: Manual of cane growing, Hogarth, M. and P. Allsopp (eds). Bureau of Sugar Experimental Stations, Indooroopilly, Australia., 91-108.

[2] Mousazadeh, A. and Mousazadeh, I. (2014) Removal of an Anionic Dye from Wastewaters by Adsorption on Modified Rice Husk and Sugarcane Bagasse. International Journal of Hybrid Information Technology, 7, 309-320.

[3] Adams, R.M. (1962) Agriculture and Urban Life in Early Southwestern Iran: Archeological survey provides a basis 
for observing broad changes during 7000 years of sedentary life. Science, 136, 109-122.

[4] Shūshtarì, M.a.B.t., Aḥmadiyān, S.l.z. and Aṣfiyā̄, Q.A. (1387) Nayshakar dar Irān. Chāp-i 1. ed. Ayìzh, Tihrān.

[5] Cutler, D.F., Botha, C.E.J. and Stevenson, D.W. (2008) Plant anatomy : an applied approach. Blackwell Pub., Malden, MA.

[6] Lawson, E.J. and Poethig, R.S. (1995) Shoot development in plants: time for a change. Trends in genetics : TIG, 11, 263-268.

[7] Poethig, R.S. (1990) Phase change and the regulation of shoot morphogenesis in plants. Science, 250, 923-930.

[8] Sylvester, A.W., Cande, W.Z. and Freeling, M. (1990) Division and differentiation during normal and liguleless-1 maize leaf development. Development, 110, 985-1000.

[9] Greenwood, M.S. (1995) Juvenility and maturation in conifers: current concepts. Tree physiology, 15, 433-438.

[10] Araki, T. (2001) Transition from vegetative to reproductive phase. Current opinion in plant biology, 4, 63-68.

[11] Bernier, G. (1986) The flowering process as an example of plastic development. Symposia of the Society for Experimental Biology, 40, 257-286.

[12] Winans, S.C., Kerstetter, R.A. and Nester, E.W. (1988) Transcriptional regulation of the virA and virG genes of Agrobacterium tumefaciens. Journal of bacteriology, 170, 4047-4054.

[13] Poethig, R.S. (1988) Heterochronic mutations affecting shoot development in maize. Genetics, 119, 959-973.

[14] Evans, M.M., Passas, H.J. and Poethig, R.S. (1994) Heterochronic effects of glossy15 mutations on epidermal cell identity in maize. Development, 120, 1971-1981.

[15] Moose, S.P. and Sisco, P.H. (1994) Glossy15 Controls the Epidermal Juvenile-to-Adult Phase Transition in Maize. The Plant cell, 6, 1343-1355.

[16] Bido Graciene de Souza, F.M.d.L.L., Marchiosi Rogério and Osvaldo Ferrarese-Filho and Ferrarese-Filho, O. (2010) Naringenin Inhibits the Growth and Stimulates the Lignification of Soybean Root. Brazilian Arcives of Biology and Technology, 53, 10.

[17] Wang, L., Showalter, A. and Ungar, I. (1997) Effect of salinity on growth, ion content, and cell wall chemistry in Atriplex prostrata (Chenopodiaceae). American journal of botany, 84, 1247.

[18] Tobimatsu, Y., Wagner, A., Donaldson, L., Mitra, P., Niculaes, C., Dima, O., Kim, J.I., Anderson, N., Loque, D., Boerjan, W. et al. (2013) Visualization of plant cell wall lignification using fluorescence-tagged monolignols. Plant $J$, $76,357-366$.

[19] Byrt, C.S., Grof, C.P. and Furbank, R.T. (2011) C4 plants as biofuel feedstocks: optimising biomass production and feedstock quality from a lignocellulosic perspective. $J$ Integr Plant Biol, 53, 120-135.

[20] Kerstetter, R.A. and Poethig, R.S. (1998) The specification of leaf identity during shoot development. Annual review of cell and developmental biology, 14, 373-398.

[21] Sylvester, A.W., Smith, L. and Freeling, M. (1996) Acquisition of identity in the developing leaf. Annual review of cell and 8.6

[22] of commercial cellulases and their use in the saccharification of a sugarcane bagasse sample pretreated with dilute sulfuric acid. Journal of industrial microbiology \& biotechnology, 38, 1089-1098.

[23] Anterola, A.M. and Lewis, N.G. (2002) Trends in lignin modification: a comprehensive analysis of the effects of genetic manipulations/mutations on lignification and vascular integrity. Phytochemistry, 61, 221-294.

[24] Rogers, L.A. and Campbell, M.M. (2004) The genetic control of lignin deposition during plant growth and development. New Phytologist, 164, 17-30.

[25] Zhao, H.Y., Wei, J.H. and Song, Y.R. (2004) [Advances in research on lignin biosynthesis and its genetic engineering]. Zhi wu sheng li yu fen zi sheng wu xue xue bao = Journal of plant physiology and molecular biology, 30, 361-370.

[26] Huckelhoven, R. (2007) Cell wall-associated mechanisms of disease resistance and susceptibility. Annu Rev Phytopathol, $45,101-127$.

[27] Bhuiyan, N.H., Selvaraj, G., Wei, Y. and King, J. (2009) Gene expression profiling and silencing reveal that monolignol biosynthesis plays a critical role in penetration defence in wheat against powdery mildew invasion. Journal of experimental botany, 60, 509-521.

[28] Goujon, T., Sibout, R., Pollet, B., Maba, B., Nussaume, L., Bechtold, N., Lu, F., Ralph, J., Mila, I., Barriere, Y. et al. (2003) A new Arabidopsis thaliana mutant deficient in the expression of O-methyltransferase impacts lignins and sinapoyl esters. Plant molecular biology, 51, 973-989.

[29] Liljegren, S. (2010) Phloroglucinol stain for lignin. Cold Spring Harbor protocols, 2010, pdb prot 4954.

[30] Gao, Z.M., Wang, X.C., Peng, Z.H., Zheng, B. and Liu, Q. (2012) Characterization and primary functional analysis of phenylalanine ammonia-lyase gene from Phyllostachys edulis. Plant cell reports, 31, 1345-1356.

[31] Hashemitabarm, M., Kolahi, M., Tabandeh, M., Jonoubi, P., Majd, M. (2014) cDNA cloning, Phylogenic Analysis and Gene Expression Pattern of Phenylalanine ammonia-lyase in Sugarcane (Saccharum officinarum L.). Brazilian Archives of Biology and Technology, 57, 10.

[32] N Joarder, A.K.R.S.N.S., K arvin. (2010) Leaf blade and midrib anatomy of two sugarcane cultivars of Bangladesh. Journal of Bio-Science, 18, 8.

[33] Li, L., Zhou, Y., Cheng, X., Sun, J., Marita, J.M., Ralph, J. and Chiang, V.L. (2003) Combinatorial modification of multiple lignin traits in trees through multigene cotransformation. Proceedings of the National Academy of Sciences of the United States of America, 100, 4939-4944.

[34] Chandler, J.W. (2008) Cotyledon organogenesis. Journal of experimental botany, 59, 2917-2931.

[35] Nelissen, H., Rymen, B., Coppens, F., Dhondt, S., Fiorani, F. and Beemster, G.T. (2013) Kinematic analysis of cell 
division in leaves of mono- and dicotyledonous species: a basis for understanding growth and developing refined molecular sampling strategies. Methods in molecular biology, 959, 247-264.

[36] Kolahi, M., Jonoubi, P., Majd, A., Tabandeh, M., Hashemitabar, M. (2013) Differential Expression of Phenylalanine Ammonia-Lyase in Different Tissues of Sugarcane (Saccharum officinarum L.) during Development. BioResources 8, 10.

[37] Esau, K. (1977) Anatomy of seed plants. 2d ed. Wiley, New York.

[38] Casu, R.E., Dimmock, C.M., Chapman, S.C., Grof, C.P., McIntyre, C.L., Bonnett, G.D. and Manners, J.M. (2004) Identification of differentially expressed transcripts from maturing stem of sugarcane by in silico analysis of stem expressed sequence tags and gene expression profiling. Plant molecular biology, 54, 503-517.

[39] Jordan, D.R., Casu, R.E., Besse, P., Carroll, B.C., Berding, N. and McIntyre, C.L. (2004) Markers associated with stalk number and suckering in sugarcane colocate with tillering and rhizomatousness QTLs in sorghum. Genome / National Research Council Canada = Genome / Conseil national de recherches Canada, 47, 988-993.

[40] Huang, J., Gu, M., Lai, Z., Fan, B., Shi, K., Zhou, Y.H., Yu, J.Q. and Chen, Z. (2010) Functional analysis of the Arabidopsis PAL gene family in plant growth, development, and response to environmental stress. Plant physiology, 153, 1526-1538.

[41] Bi, C., F. Chen, L. Jakson, B.S Gill and W. Li. (2011) Expression of lignin biosynthetic genes in Wheat during development and upon infection by fungal pathogens. Plant Mol Biol Rep, 29, 11.

[42] Patten, A.M., Cardenas, C.L., Cochrane, F.C., Laskar, D.D., Bedgar, D.L., Davin, L.B. and Lewis, N.G. (2005) Reassessment of effects on lignification and vascular development in the irx4 Arabidopsis mutant. Phytochemistry, 66, 2092-2107.

[43] Vanholme, R., Morreel, K., Ralph, J. and Boerjan, W. (2008) Lignin engineering. Current opinion in plant biology, 11, 278-285. 